\title{
Identification of limonene as a potential kairomone of the harlequin ladybird Harmonia axyridis (Coleoptera: Coccinellidae)
}

\author{
AMmAR ALHMEDI, ERIC HAUBRUGE and FrÉDÉRIC FRANCIS
}

\begin{abstract}
Department of Functional and Evolutionary Entomology, Gembloux Agro-Bio Tech, University of Liège, Passage des Déportés 2 , B-5030 Gembloux, Belgium; e-mails: alhmedi_a@yahoo.fr; E.Haubruge@ulg.ac.be; Frederic.Francis@ulg.ac.be
\end{abstract}

Key words. Coccinellidae, Harmonia axyridis, four-arm olfactometer, host location, induced semiochemical, limonene, $\beta$-caryophyllene, natural enemies, oviposition stimulant, pest management

\begin{abstract}
Chemical cues involved in both host location and oviposition by Harmonia axyridis Pallas (Coleoptera: Coccinellidae) were investigated in laboratory and field experiments. Among the five volatiles tested in a four-arm olfactometer ((E)- $\beta$-farnesene, $\beta$-pinene, $\beta$-caryophyllene, cis-3-hexen-1-ol, and limonene), gravid $H$. axyridis females were significantly attracted to limonene and $\beta$-caryophyllene. These two chemicals also increased $H$. axyridis oviposition on plants. Attraction of $H$. axyridis towards limonene was further tested under field conditions using controlled-release dispensers. (E)- $\beta$-farnesene, a major aphid alarm pheromone and a potential predator kaironome, was also tested in this study. Field data confirmed those from laboratory studies concerning the attraction of H. axyridis towards limonene and a lack of response to (E)- $\beta$-farnesene. In contrast, the aphid predator Episyrphus balteatus DeGeer (Diptera: Syrphidae) was attracted to (E)- $\beta$-farnesene but not to limonene. These findings indicate that $H$. axyridis uses chemicals, such as limonene, for prey location and oviposition, and support the potential use of volatiles in the management of $H$. axyridis.
\end{abstract}

\section{INTRODUCTION}

Semiochemicals released by plants in response to herbivore attack and the subsequent use of these chemical signals by natural enemies to locate these herbivores is a widespread phenomenon observed in various tritrophic systems. These volatile compounds may serve as a part of the plant defense mechanism by attracting natural enemies during pest colonisation and thereby limiting pest damage on the plant, e.g. the generalist predatory mite Neoseiulus californicus McGregor on Lima bean vs. the spider mite, Tetranychus urticae Koch (Shimoda et al., 2005), parasitic wasps (Cotesia marginiventris Cresson, Microplitis rufiventris Kok., Campoletis sonorensis Cameron vs. Spodoptera littoralis Boisduval on cotton (Gouinguené et al., 2005), and the anthocorid predator Anthocoris nemoralis Fabricius vs. the psyllid Psylla pyricola on pear trees (Scutareanu et al., 1997). Similar evidence was found for semiochemicals, e.g. (E)- $\beta$-farnesene, released by herbivores, e.g. aphids, in response to natural enemy attack; natural enemies use these chemical signals to locate their prey, e.g. the ladybird species Coccinella septempunctata L. (Al Abassi et al., 2000; Ninkovic et al., 2001) and Adalia bipunctata L. (Hemptinne et al., 2000; Francis et al., 2004), and the hoverfly Episyrphus balteatus DeGeer (Francis et al., 2005a; Verheggen et al., 2008) were attracted to (E)- $\beta$-farnesene emitted from aphids.

Promising field evidence for the attraction of natural enemies to synthetic plant volatiles was obtained by James (2003a, b), James et al. (2003) and James \& Price (2004) who demonstrated attraction of a number of natural enemy species to methyl salicylate, e.g. Chrysopa nigricornis Burmeister, Geocoris pallens Stal., Stethorus punctum picipes Casey, Deraeocoris brevis Uhler, and Orius tristicolor White.

Over the last 30 years, the behavioural manipulation of insects through semiochemical techniques, e.g. push-pull strategies, has been considered for the control of insect populations, with varying success (Cook et al., 2007). Information on semiochemically-mediated behavioural mechanisms of ladybirds is limited (Pettersson et al., 2005) but there are sufficient recent studies to suggest that, as in other insects, chemical communication is an important component of ladybird behaviour (Majerus, 1994; Burns et al., 1998; Hemptinne et al., 2004; Pettersson et al., 2005). Ladybirds are subjected to various chemical blends when searching for an oviposition site. These blends consist of plant and insect semiochemicals such as (E)- $\beta$-farnesene as the main component of the alarm pheromone of most aphid species, $\beta$-pinene, and limonene (Nault et al., 1973; Francis et al., 2005b).

The harlequin ladybird Harmonia axyridis Pallas (Coleoptera: Coccinellidae) is an effective biological control agent employed against different insect species, particularly aphids (Hodek \& Honěk, 1996; Lucas et al., 2007), in various agro-ecosystems (e.g., Michaud, 2002; Brown, 2004). Other insect prey included Tetranychidae (Lucas et al., 1997), Psyllidae (Michaud, 2004), Coccoidea (McClure, 1986), Chrysomelidae (Snyder \& Clevenger, 2004), Curculionidae (Kalaskar \& Evans, 2001; Stuart et al., 2002) and Lepidoptera (Koch et al., 2005). However, $H$. axyridis has adverse impacts, e.g. a decline in native natural enemies due to impacts on non-target arthropods (Alyokhin \& Sewell, 2004; Majerus et al., 2006; Roy et 
TABLE 1. The source, purity, biological source and biological role of each chemical tested for behavioural responses.

\begin{tabular}{lcccc}
\hline Molecule & Source & Purity & Biological source & Main biological role \\
\hline$\beta$-Farnesene & $\begin{array}{c}\text { Department of Analytical chemistry, } \\
\text { Liege University, Gembloux } \\
\text { Agro-BioTech, Gembloux, Belgium }\end{array}$ & $\geq 81.48 \%$ & $\begin{array}{c}\text { Extraction from Matricaria } \\
\text { chamomilla } \text { fractionation } \\
\text { (by flash chromatography) }\end{array}$ & $\begin{array}{c}\text { Aphid alarm pheromone } \\
\text { (Francis et al., 2005b) }\end{array}$ \\
$\begin{array}{l}\text { Limonene } \\
\beta \text {-Caryophyllene }\end{array}$ & Sigma-Aldrich & $\geq 98.5 \%$ & Chemical synthesis & $\begin{array}{c}\text { Harmonia axyridis aggregation } \\
\text { pheromone (Verheggen et al., 2007) } \\
\text { Aphid alarm pheromone }\end{array}$ \\
Cis-3-hexen-1-ol & Sigma-Aldrich & $\geq 90.5 \%$ & Chemical synthesis & $\begin{array}{c}\text { Aphical synthesis } \\
\text { (Pickett \& Griffiths, 1980) } \\
\text { Aphid alarm pheromone } \\
\text { (Pickett \& Griffiths, 1980) } \\
\text { Defensive plant volatile } \\
\text { (Kessler \& Baldwin, 2001) }\end{array}$ \\
\hline
\end{tabular}

al., 2006), and as a nuisance pest due to mass aggregations of overwintering $H$. axyridis populations in houses, barns, and other man-made structures (Nalepa et al., 1996, 2004; Kuznetsov, 1997; Huelsman \& Kovach, 2004).

The spatial distribution of $H$. axyridis populations in Belgium is clearly associated with non-crop habitats, e.g. such as deciduous trees, pine trees and various herbaceous habitats (e.g., Adriaens et al., 2003, 2008; Alhmedi et al., 2007). Therefore, an understanding of the chemical ecology of $H$. axyridis is essential before developing pest management strategies, first for the efficient use of this species in aphid biocontrol, and second for efficient $H$. axyridis management programs in agro-ecosystems which could help counter the declines particularly in predator diversity associated with its arrival (Pell, 2008).

In the present study, the olfactory and oviposition responses of adult female $H$. axyridis towards a range of chemical cues, limonene, (E)- $\beta$-farnesene, $\beta$-pinene, $\beta$-caryophyllene and cis-3-hexen-1-ol, are investigated in the laboratory. These volatiles released by plants, aphids and natural enemies are often detectible where $H$. axyridis occur (e.g., Turlings et al., 1995; Moraes et al., 1998, 2001; Michaud, 2002; Francis et al., 2005b; Brown et al., 2006; Verheggen et al., 2007), and could be used to improve pest management programs. A field study aimed to test the behavioural responses of aphid predators, particularly $H$. axyridis, towards limonene and (E)- $\beta$ farnesene was also conducted.

\section{MATERIAL AND METHODS}

\section{Plant and insect rearing}

Broad beans (Vicia faba L.) were planted in plastic pots (12 $\mathrm{cm}$ diameter; $10 \mathrm{~cm}$ height) containing a $1: 1$ mixture of perlite : vermiculite at $22 \pm 2{ }^{\circ} \mathrm{C}$ and $16 \mathrm{~L}: 8 \mathrm{D}$ and grown in a culture room. The aphid Megoura viciae Buckton was reared on host bean plants in similar conditions. Mass rearing of $H$. axyridis was maintained for many years in the laboratory. Both adults and larvae were reared in aerated plastic boxes $(10 \times 30 \times 10$ $\mathrm{cm}$; up to 20 individuals per container) and fed with $M$. viciae on $V$. faba. Boxes were placed in controlled environment incubators, $16 \mathrm{~L}: 8 \mathrm{D}$ and $22 \pm 2{ }^{\circ} \mathrm{C}$. Four-week old $H$. axyridis females were used in olfactory and oviposition experiments.

\section{Olfactory experiments}

Behavioural bioassays with $H$. axyridis females toward several plant and aphid volatiles (limonene, (E)- $\beta$-farnesene, $\beta$-pinene, $\beta$-caryophyllene and cis-3-hexen-1-ol; Table 1) were conducted in a four-arm olfactometer similar to that described previously (Pettersson, 1970; Vet et al., 1983). Using a digital pump, charcoal-filtered air was propelled through each of the four olfactometer arms along PTFE tubing at a flow rate of 50 $\mathrm{ml} / \mathrm{min}$. For tests involving a single volatile, a glass flask containing $5 \mu \mathrm{g}$ of the experimental volatile impregnated on a $1-\mathrm{cm}^{2}$ piece of Whatman \#1 filter paper was connected at random to one of the four olfactometer arms while the other three arms were connected to blank controls.

The walking arena, the glass ceiling and the glass flask were washed with pure ethanol and then rinsed with distilled water after each replicate. The olfactometer was placed in a controlled temperature room at $22 \pm 2{ }^{\circ} \mathrm{C}$ under uniform lighting. Gravid female adults ( $\mathrm{N}=20$ per stimulus) were observed independently for $15 \mathrm{~min}$ in the olfactometer (one female / replicate). The arena was divided into one central squared $10-\mathrm{cm}$ (in diameter) zone and four other zones related to the four odour sources. The source of the volatile was changed to a different location after assaying five adults. The olfactory response of the ladybird was determined by (a) the first zone it entered (the first choice), and (b) the zone where it passed the longest duration during $15 \mathrm{~min}$ (the \% of time spent in each area).

\section{Oviposition bioassays}

The oviposition behaviour of $H$. axyridis was investigated toward the following volatiles: (E)- $\beta$-farnesene, $\beta$-pinene, $\beta$-caryophyllene, cis-3-hexen-1-ol and limonene. Experiments were conducted in cylindrical plastic cages $(9 \mathrm{~cm}$ diameter $\times 25$ $\mathrm{cm}$ height) with 4-week-old gravid females. The fertility of all females used was assessed three days prior to the test by counting the eggs laid on potted broad bean plants infested with $M$. viciae. Great care was taken to insure that all females used in oviposition assays had similar fertility and all host plants were of similar size. All $H$. axyridis females used had no exposure to aphids for one day before ovipositional tests. A single gravid female ( $\mathrm{N}=10$ per each volatile) was carefully introduced into each cage containing a $1-\mathrm{cm}$ (in diameter) rubber septum fixed around the stem close to the apex of the potted plant. The volatiles were added to the rubber septa using a micropipette at 100 $\mu 1[100 \mathrm{ng} / \mu \mathrm{l}]$ per septum. The oviposition response of the $H$. axyridis females to the induced volatiles was compared with two control types: (1) negative control is potted healthy plant without introduced volatile, (2) positive control is potted plant with M. viciae aphid (200 aphids / plant). Eggs laid after two and six hours were recorded in each replicate. Ten replicates 


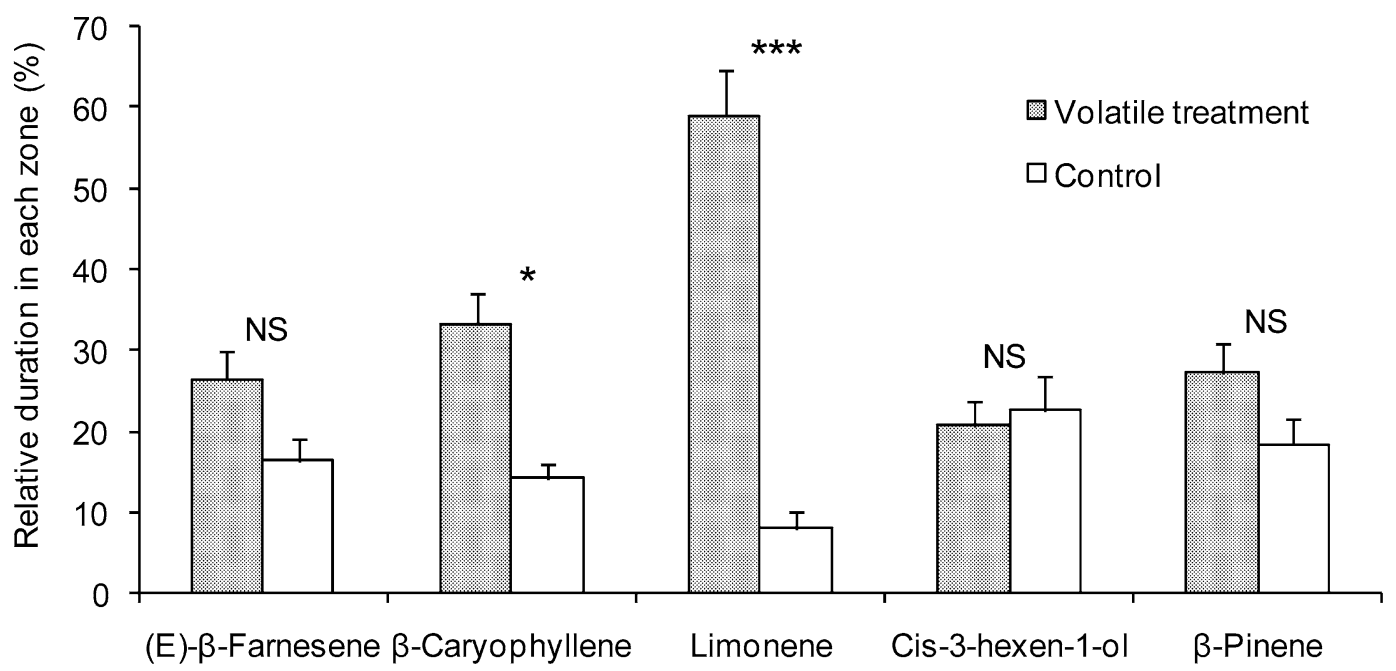

Fig. 1. Mean relative period ( $\pm \mathrm{SE}$ ) spent in each odour zone of a four-arm olfactometer by $H$. axyridis females exposed to various host plant and aphid volatiles. Control represents the mean values of control fields (air only). NS, * and *** indicate not significant, significant $(\mathrm{p}<0.05)$ and very significant differences $(\mathrm{p}<0.001)$.

were run simultaneously for each test. In both positive and negative controls there were no volatiles tested.

\section{Field study}

The field study was conducted during summer (from late July to late August) 2009 in a 5 ha chicory (Cichorium intybus L.) crop field located at the experimental farm of Gembloux Agro-Bio Tech (Gembloux, Belgium) and close to a 3 ha woodland. Controlled-release dispensers containing $100 \mu 1[1 \mathrm{mg} /$ $100 \mu \mathrm{l}]$ of either limonene or (E)- $\beta$-farnesene were prepared and installed on yellow water pan traps. These were deployed randomly at $1 \mathrm{~m}$ above ground level in two blocks separated by 100 $\mathrm{m}$. Yellow traps with water containing paraffin dispensers served as unbaited controls. The dispensers were replaced weekly. In each block, 9 traps ( 3 of each type) were installed randomly, where each set of 3 traps were positioned in a row (i.e. 1 baited with limonene, 1 baited with (E)- $\beta$-farnesene, and 1 control); the distance between each two traps was $25 \mathrm{~m}$. Populations of aphid predators were sampled 10 times (twice per week) from late July to late August, counted and identified to species. On each sampling date, 10 plants were chosen randomly near each yellow trap and searched for aphids and other potential arthropod herbivores.

\section{Statistical analyses}

Results were analysed using Minitab 15.0. Observed frequencies related to the choice of $H$. axyridis and other aphid predators in localising prey were compared to corresponding theoretical frequencies using a $\chi^{2}$ goodness-of-fit test. Relative stay durations of $H$. axyridis adults in the olfactory study ( $\%$ of total time spent in odour zone) were analysed using a one-sample t-test to test the hypothesis that the mean value observed is higher than 0.25 (i.e. 25\%). The oviposition responses of $H$. axyridis females to the volatiles were compared to negative controls using General Linear Model and Dunnett's test. Prior to the analysis, data were checked for equal variances and normality, and transformed to $\log _{10}(n+1)$ if necessary.

\section{RESULTS}

\section{Olfactometer experiments}

When observing the first zone entered, female $H$. axyridis did not exhibit any significant preference for the volatiles compared to controls, $\left(\chi^{2}=4.80\right.$, d.f. $=3, \mathrm{P}=$ 0.187 for limonene; $\chi^{2}=1.60$, d.f. $=3, \mathrm{P}=0.659$ for (E)- $\beta$-farnesene; $\chi^{2}=6.05$, d.f. $=3, \mathrm{P}=0.109$ for $\beta$-caryophyllene; $\chi^{2}=0.40$, d.f. $=3, \mathrm{P}=0.940$ for $\beta$-pinene; $\chi^{2}=2.00$, d.f. $=3, P=0.572$ for cis-3-hexen-1ol).

Nonetheless, significant differences were detected in the times spent in two volatile zones compared to control zones. Harmonia axyridis females spent significantly more time in either limonene or $\beta$-caryophyllene zones $(\mathrm{t}$ $=6.07$ and $\mathrm{P}<0.001 ; \mathrm{t}=2.16$ and $\mathrm{P}=0.043$, respectively) compared to controls (Fig. 1). In contrast, significant differences were not detected in the percentage time spent by females in either (E)- $\beta$-farnesene, $\beta$-pinene or cis-3-hexen-1-ol zones $(\mathrm{t}=0.41$ and $\mathrm{P}=0.688 ; \mathrm{t}=$ 0.61 and $\mathrm{P}=0.552 ; \mathrm{t}=-1.41$ and $\mathrm{P}=0.174$, respectively), compared to controls (Fig. 1).

\section{Oviposition responses of $\boldsymbol{H}$. axyridis females to plant and aphid volatiles}

Among the five volatiles tested in the current study, only limonene and $\beta$-caryophyllene, elicited a significant oviposition responses from $H$. axyridis females (Table 2). During the first two hours of exposure, a significant oviposition response to $\beta$-caryophyllene presence on the broad bean plants $\left(\mathrm{F}_{1,18}=8.45\right.$ and $\left.\mathrm{P}=0.009\right)$ was observed. Limonene induced ovipositional behaviour in females but only during the second duration of observation $\left(\mathrm{F}_{1,18}=6.74\right.$ and $\left.\mathrm{P}=0.018\right)$ (compared to the negative control). Significant differences were also detected in the total numbers of eggs laid as a response to either $\beta$-caryophyllene or limonene presence $\left(\mathrm{F}_{1,18}=4.71\right.$ and $\mathrm{P}$ $=0.044 ; \mathrm{F}_{1,18}=4.84$ and $\mathrm{P}=0.041$, respectively) when compared to the negative control. Among the volatiles tested, only limonene stimulated significantly oviposition of $H$. axyridis females during the $2-6 \mathrm{~h}$ period $\left(\mathrm{F}_{1,18}=\right.$ 5.17 and $\mathrm{P}=0.035$ ) when compared to the positive control. Harmonia axyridis females did not show any signifi- 
TABLE 2. Mean number ( \pm SE) of eggs laid by $H$. axyridis females $(\mathrm{N}=10$ per each chemical) on plants either treated with chemicals or infested with M. viciae aphids (positive control) compared to negative control plants $(V . f a b a)$. Negative control was a healthy plant without introduced chemical.

\begin{tabular}{lccc}
\hline Treatment & \multicolumn{3}{c}{ Number of eggs laid } \\
\cline { 2 - 4 } & From 0 to 2 h & From 2 to 6 h & Total \\
\hline Negative control & $2.2 \pm 1.5$ & $8.4 \pm 3.2$ & $10.6 \pm 3.2$ \\
Positive control & $19.9 \pm 6.3^{* *}$ & $7.2 \pm 3.5$ & $27.1 \pm 4.8^{* *}$ \\
Limonene & $0.0 \pm 0.0$ & $22.80 \pm 4.6^{*}$ & $22.8 \pm 4.6^{*}$ \\
(E)- $\beta$-farnesene & $1.7 \pm 1.1$ & $3.80 \pm 1.8$ & $5.5 \pm 2.1$ \\
$\beta$-pinene & $0.0 \pm 0.0$ & $19.00 \pm 5.3$ & $19.0 \pm 5.3$ \\
(-)- $\beta$-caryophyllene & $12.5 \pm 3.2^{* *}$ & $8.50 \pm 3.4$ & $21.0 \pm 3.6^{*}$ \\
Cis-3-hexen-1-ol & $1.5 \pm 1.5$ & $13.30 \pm 3.9$ & $14.8 \pm 4.2$
\end{tabular}

Compared to the negative control, * indicates significant at $\mathrm{P}<$ 0.05 , and $* *$ indicates significant at $\mathrm{P}<0.001$ using Dunnett's test.

cant oviposition responses to (E)- $\beta$-farnesene, $\beta$-pinene, or cis-3-hexen-1-ol compared to the negative control. The number of eggs laid were similarly not significantly different from the negative control (Table 2).

\section{Field study}

Aphid populations were low in the chicory field (only 3-5 Myzus persicae Sulzer individuals were recorded on all plants scanned) and other insect herbivores were absent on crop plants during study period. Significantly greater numbers of two species of aphid predators, $H$. axyridis and $E$. balteatus were trapped in the yellow traps containing either limonene or (E)- $\beta$-farnesene (for $H$. axyridis, $\chi^{2}=23.06$, d.f. $=1$ and $\mathrm{P}<0.001 ; \chi^{2}=3$, d.f. $=$ 1 and $\mathrm{P}=0.083$; for E. balteatus, $\chi^{2}=0$, d.f. $=1$ and $\mathrm{P}=$ $1 ; \chi^{2}=21.78$, d.f. $=1$ and $\mathrm{P}<0.001$, respectively; Fig. 2 ). Other aphid predators caught in the yellow traps were at lower totals and ranged from 1 to 13 individuals, they included Coccinella septempunctata L. (8 indiv.), Propylea quatuordecimpunctata L. (1 indiv.) (Coleoptera: Coccinellidae), Sphaerophoria scripta L. (2 indiv.), Melanostoma mellinum L. (13 indiv.), Eupeodes corollae L. (2 indiv.), Eupeodes latilunulatus Collin (1 indiv.) (Diptera: Syrphidae), and Chrysoperla carnea Stephens (4 indiv.) (Neuroptera: Chrysopidae).

\section{DISCUSSION}

The current study demonstrates field and laboratory attraction of $H$. axyridis to a synthetic formulation of limonene, but also confirms laboratory data obtained by Francis et al. (2005a) and Verheggen et al. (2008) concerning the attractiveness of $(\mathrm{E})$ - $\beta$-farnesene to the common hoverfly $E$. balteatus. In the laboratory study, we found that both limonene and $\beta$-caryophyllene elicited attractant and oviposition responses from $H$. axyridis females, indicating that the harlequin ladybird might use these chemical cues in locating both prey and oviposition sites. The ladybirds Coleomegilla maculata DeGeer (Zhu et al., 1999), Chilocorus nigritus Fabricius (Ponsonby \& Copland, 1995), and Cryptolaemus montrouzieri Mulsant

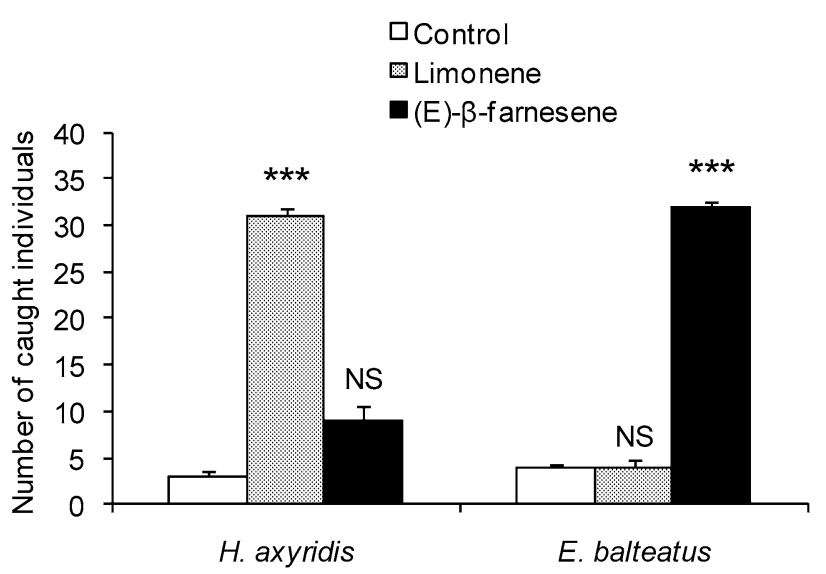

Fig. 2. Total numbers ( $\pm \mathrm{SD})$ of E. balteatus and H. axyridis caught in the different treatments using yellow traps with water, compared to the control (chemical-free dispenser). NS and $* * *$ indicate not significant and significant $(\mathrm{p}<0.001)$.

(Heidari \& Copland, 1992) are known to use olfactory cues in host location at some level.

Initially in the olfactory experiments, $H$. axyridis females had no significant preference towards any of the volatiles compared with controls. This behavioural response recorded in the present study for $H$. axyridis females towards the volatiles may be due to either, or a combination of, the volatile concentration applied and that arthropods may require different recognition times to identify the odour source. Signal intensity for orientation decreases with distance and increases with concentration of the source (Stanton, 1983; Elkinton et al., 1987). It has been demonstrated that insects move randomly at low odour concentrations but that this movement becomes increasingly directed towards chemical source as odour concentration increases (Cardé, 1996). Once a chemical attractant is detected in the air, the insect begins searching and moving toward the direction of increasing odour concentration (Cardé, 1996). The searching and host-finding behaviour of parasitoids has been widely studied (e.g., Lewis et al., 1982; Colazza et al., 2001), but comparatively little attention has been given to coccinellid predators. De Boer et al. $(2004,2005)$ and van Wijk et al. (2008) reported on the behavioural responses of Phytoseiulus persimilis Athias-Henriot (Acarina: Phytoseiidae), a predatory mite that preys on the highly polyphagous herbivore Tetranychus urticae Koch (Acari: Tetranychidae). In laboratory experiments these authors found that the predatory mites require a brief learning period of less than 15 min to show a preference for an odour.

Limonene is a potential kairomone of $H$. axyridis and females spent significantly more time in limonene zones than in control zones. This chemical cue is also attractive to other biocontrol agents such as Medetera setiventris Thuneberg (Diptera: Dolichopodidae) (Hulcr et al., 2006), a predator of the spruce bark beetle Ips typographus L. (Coleoptera: Scolytidae), and Dastarcus helophoroides Fairmaire (Coleoptera: Bothrideridae), a parasitoid of Massicus raddei Blessig (Coleoptera: Cerambycidae) (Wei et al., 2008). Similarly, H. axyridis 
females spent significantly more time in $\beta$-caryophyllene zones than in controls confirming the finding obtained by Verheggen et al. (2007). $\beta$-caryophyllene was already detected as an attractant for other species such as the damson hop aphid Phorodon humuli Schrank (Campbell et al., 1993), and the green lacewing C. carnea (Flint et al., 1979).

In the present study, $H$. axyridis did not respond to (E)- $\beta$-farnesene. This finding agrees with Mondor \& Roitberg (2000) but disagrees with Verheggen et al. (2007). Two potential hypotheses might explain our observations and explain this inconsistency: (i) the behavioural response of insects are known to be modified according to the volatile concentration applied (Schlyter et al., 1989; Zhu et al., 1999; Bhasin et al., 2000), and (ii) the potential emission of $\beta$-caryophyllene by $H$. axyridis females (Brown et al., 2006) during the experimental period. Several authors found that the behavioural response of another ladybird, $C$. septempunctata, to (E)- $\beta$-farnesene was inhibited in the presence of $\beta$-caryophyllene (Dawson et al., 1984; Al Abassi et al., 2000). In fact, among aphidophagous species some responded to the (E)- $\beta$-farnesene such as $A$. bipunctata (Hemptinne et al., 2000; Francis et al., 2004), C. septempunctata (Nakamuta, 1991; Al Abassi et al., 2000), and E. balteatus (Francis et al., 2005a; Verheggen et al., 2008) but others did not, such as Chrysopa cognata McLachlan (Boo et al., 1998). On the other hand, neither cis-3-hexen1-ol nor $\beta$-pinene elicited significant behavioural responses from $H$. axyridis females in our current study. In contrast to this finding, Dicke et al. (1990) and van Wijk et al. (2008) reported the attractiveness of cis-3hexen-1-ol to the predatory mite $P$. persimilis. Similarly, Mizell et al. (1984) described the attractiveness of $\beta$-pinene to Thanasimus dubius Fabricius, a predator of bark beetles in eastern North America.

In a review on plant volatile-natural enemy interactions, Hunter (2002) stated that although the laboratory evidence of the behavioural responses of natural enemies towards semiochemicals emitted by herbivores and plants is now well investigated, few studies have been published showing the response of natural enemies to these compounds under field conditions. The evidence linked to our field data and presented here suggests that the use of a controlled-release synthetic chemical in a crop can increase the population density of certain beneficial insects, i.e. such as controlled-release synthetic limonene for the ladybird $H$. axyridis and controlled-release synthetic (E)- $\beta$-farnesene for the hoverfly $E$. balteatus. Limonene is known as plant volatile, but also emitted by some aphid species (Francis et al., 2005b). Michaud (2002) reported an extraordinary ability of $H$. axyridis to locate pest infested citrus plants. Citrus plants are known as the principal source of limonene and this observation may potentially explain our results of the behavioural responses of $H$. axyridis toward this chemical compound. Moreover, Francis et al. (2005a) and Verheggen et al. (2008) reported the attractiveness of (E)- $\beta$-farnesene to the hoverfly $E$. balteatus. Results from our study suggest that the use of attractant chemicals, such as limonene, in an agro-system may have the potential to modify the behavioural responses of $H$. axyridis where the spatial distribution recorded for $H$. axyridis populations in Belgium was strongly linked to semi-natural habitats (e.g., Alhmedi et al., 2007; Adriaens et al., 2003, 2008). The chemical ecology of multitrophic interactions between plants, aphids, and natural enemies has been widely studied for exploitation of beneficial insects in biological control programs (Pickett et al., 1991; Takabayashi \& Dicke, 1996; Bottrell \& Barbosa, 1998; Thaler, 1999, 2002; James, 2003a, b; James \& Price, 2004).

The presence of either limonene or $\beta$-caryophyllene in plants, compared to negative control, stimulated significantly the oviposition behaviour of $H$. axyridis females, suggesting that selection of the oviposition site by $H$. axyridis depends on the perception of volatile cues released by prey and host plants. Shu et al. (1997) found that limonene acts as a significant ovipositional stimulant in Dioryctria abietivorella Groté females (Lepidoptera: Pyralidae). Although there is little information in the literature as to how $\beta$-caryophyllene influences oviposition behaviour in insects, Johne et al. (2006) found that this chemical, when released from blossoms of the host tree, increased oviposition of Cameraria ohridella Deschka \& Dimic females (Lepidoptera: Gracillariidae), a leaf miner insect pest.

In contrast, the presence of either (E)- $\beta$-farnesene, cis3 -hexen-1-ol or $\beta$-pinene on host plants did not significantly induce oviposition behaviour in $H$. axyridis females compared to the negative control. This is explained by non-attraction of these chemicals for $H$. axyridis females, as found in the current study. In contrast to these behavioural responses, the oviposition of other predator females, including $T$. dubius and E. balteatus, was induced in response to the presence of $\beta$-pinene and (E)- $\beta$-farnesene, respectively (Mizell et al., 1984; Verheggen et al., 2008).

Many insects are known to show different behavioural responses according to the concentration of the volatile cue applied (Zhu et al., 1999; Bhasin et al., 2000). Further study is needed on the behavioural response of $H$. axyridis towards semiochemicals at different concentrations. Based on our findings, push-pull strategies that target the use of $H$. axyridis as a biological control agent in aphidinfested sites, should take into account the attractive effect that limonene could have in field conditions.

In conclusion, the use of synthetic formulations of limonene in field crops may conceivably have two benefits to pest management; (i) increase the populations of beneficial insects such as $H$. axyridis necessary for aphid pest biocontrol, and (ii) better management of field $H$. axyridis populations in agro-ecosystems, which could help counter declines particularly in predator diversity associated with its arrival (Pell, 2008). Further work is therefore needed to study the potential effect of limonene on the intraguild interactions among aphidophagous guilds which include $H$. axyridis. 
ACKNOWLEDGEMENTS. The authors are grateful to G. Lognay, from Gembloux Agro-Bio Tech, Liège University, for providing with semiochemical cues. We also thank Y. Brostaux, from Gembloux Agro-Bio Tech, University of Liege, for help in statistical analysis.

\section{REFERENCES}

Adriaens T., Branquart E. \& Maes D. 2003: The multicoloured Asian ladybird Harmonia axyridis Pallas (Coleoptera: Coccinellidae), a threat for native aphid predators in Belgium? Belg. J. Zool. 133: 195-196.

Adriaens T., San Martin y Gomez G. \& Maes D. 2008: Invasion history, habitat preferences and phenology of the invasive ladybird Harmonia axyridis in Belgium. BioControl 53: 69-88.

Al Abassi S.A., Birkett M.A., Pettersson J., Pickett J.A., Wadhams L.J. \& Woodcock C.M. 2000: Response of the seven-spot ladybird to an alarm pheromone and an alarm pheromone inhibitor is mediated by paired olfactory cells. $J$. Chem. Ecol. 26: 1765-1771.

Alhmedi A., Haubruge E., Bodson B. \& Francis F. 2007: Aphidophagous guilds on nettle (Urtica dioica) strips close to fields of green pea, rape and wheat. Insect Sci. 14: 419-424.

Alyokhin A. \& Sewell G. 2004: Changes in a lady beetle community following the establishment of three alien species. Biol. Invasions 6: 463-471.

Bhasin A., Mordue A.J. \& Mordue W. 2000: Electrophysiological and behavioral identification of host kairomones as olfactory cues for Culicoides impuntatus and C. nubeculosis. Physiol. Entomol. 25: 6-16.

Boo K.S., Chung I.B., Han K.S., Pickett J.A. \& Wadhams L.J. 1998: Response of the lacewing Chrysopa cognata to pheromones of its aphid prey. J. Chem. Ecol. 24: 631-639.

Bottrell D.G. \& BARBosa P. 1998: Manipulating natural enemies by plant variety selection and modification: A realistic strategy? Annu. Rev. Entomol. 43: 347-367.

Brown M.W. 2004: Role of the aphid predator guild in controlling spirea aphid populations on apple in West Virginia, USA. Biol. Control 29: 189-198.

Brown A.E., Riddick E.W., Aldrich J.R. \& Holmes W.E. 2006: Identification of (-)- $\beta$-caryophyllene as a gender-specific terpene produced by the multicolored Asian lady beetle. $J$. Chem. Ecol. 32: 2489-2499.

Burns D.A., McDonnell J.J., Hemptinne J.-L., Lognay G. \& Dixon A.F.G. 1998: Mate recognition in the two-spot ladybird beetle, Adalia bipunctata: role of chemical and behavioural cues. J. Insect Physiol. 44: 1163-1171.

Campbell C.A.M., Pettersson J., Pickett J.A., Wadhams L.J. \& WoodCock C.M. 1993: Spring migration of damson hop aphid, Phorodon humuli (Homoptera, Aphididae), and summer host plant derived semiochemicals released on feeding. J. Chem. Ecol. 19: 1569-1576.

CARDÉ R.T. 1996: Odour plumes and odour-mediated flight in insects. In Bock G.R. \& Cardew G. (eds): Olfaction in Mosquito-host Interactions. Ciba Foundation Symposium 200, John Wiley \& Sons, Chichester, pp. 54-70.

Colazza S., Fucarino A., Peri E., Salermo G., Conti E. \& Bin F. 2001: Cues mediating host location in Trissolcus basalts: The role of volatiles induced by host eggs-plant interaction. In Proceedings of the 18th Annual Meeting of the International Society of Chemical Ecology, Lake Tahoe, 81 pp.

Cook S.M., Khan Z.R. \& Pickett J.A. 2007: The use of pushpull strategies in integrated pest management. Annu. Rev. Entomol. 52: 375-400.
Dawson G.W., Griffiths D.C., Pickett J.A., Smith M.C. \& Woodcock C.M. 1984: Natural inhibition of aphid alarm pheromone. Entomol. Exp. Appl. 36: 197-199.

De Boer J.G., Posthums M.A. \& Dicke M. 2004: Identification of volatiles that are used in discrimination between plants infested with prey or nonprey herbivores by a predatory mite. J. Chem. Ecol. 30: 2215-2230.

De Boer J.G., Snoeren T.A.L. \& Dicke M. 2005: Predatory mites learn to discriminate between plant volatiles induced by prey and nonprey herbivores. Anim. Behav. 69: 869-879.

Dicke M., Sabelis M.W., Takabayashi J., Bruin J. \& Posthums M.A. 1990: Plant strategies of manipulating predator-prey interactions through allelochemicals: prospects for application in pest control. J. Chem. Ecol. 16: 3091-3118.

Elkinton J.S., Schal C., Ono T. \& Cardé R.T. 1987: Pheromone puff trajectory and upwind flight of male gypsy moths in a forest. Physiol. Entomol. 12: 399-406.

Flint H.M., Salter S.S. \& Walters S. 1979: Caryophyllene: An attractant for the green lacewing. Environ. Entomol. 8: 1123-1125.

Francis F., Lognay G. \& Haubruge E. 2004: Olfactory responses to aphid and host plant volatile releases: $\mathrm{E}-\beta$ farnesene an effective kairomone for the predator Adalia bipunctata. J. Chem. Ecol. 30: 741-755.

Francis F., Martin T., Lucas G. \& Haubruge E. 2005a: Role of (E)- $\beta$-farnesene in systematic aphid prey location by Episyrphus balteatus larvae (Diptera: Syrphidae). Eur. J. Entomol. 102: $431-436$.

Francis F., Vandermoten S., Verheggen F., Lognay G. \& HauBRUGE E. 2005b: Is the (E)- $\beta$-Farnesene only volatile terpenoid in aphids? J. Appl. Entomol. 129: 6-11.

Gouinguené S., Pickett J.A., Wadhams L.J., Birkett M.A. \& TuRLINGS T.C.J. 2005: Antennal electrophysiological responses of three parasitic wasps to caterpillar-induced volatiles from maize (Zea mays), cotton (Gossypium herbaceum), and cowpea (Vigna unguiculata). J. Chem. Ecol. 31: 1023-1038.

Heidari M. \& Copland M.J.W. 1992: Host finding by Cryptolaemus montrouzieri (Col., Coccinellidae) a predator of mealybugs (Hom. Pseudococcidae). Entomophaga 37: 621-625.

Hemptinne J.L., Gaudin M., Dixon A.F.G. \& Lognay G. 2000: Social feeding in ladybird beetles: adaptive significance and mechanism. Chemoecology 10: 149-152.

Hemptinne J.-L., Lognay G., Doumbia M. \& Dixon A.F.G. 2004: Chemical nature and persistence of the oviposition deterring pheromone in the tracks of the larvae of the two spot ladybird, Adalia bipunctata (Coleoptera: Coccinellidae). Chemoecology 11: 43-47.

Hodek I. \& HonĚK A. 1996: Ecology of Coccinellidae. Kluwer Academic Publishers, Dordrecht, 464 pp.

Huelsman M.F. \& Kovach J. 2004: Behavior and treatment of the multicolored Asian lady beetle (Harmonia axyridis) in urban environments. Am. Entomol. 50: 163-164.

Hulcr J., UbiK K. \& VRKOC J. 2006: The role of semiochemicals in tritrophic interactions between the spruce bark beetle Ips typographus, its predators and infested spruce. J. Appl. Entomol. 130: $275-283$.

Hunter M.D. 2002: A breath of fresh air: Beyond laboratory studies of plant volatile-natural enemy interactions. Agr. Forest Entomol. 4: 81-86.

JAMES D.G. 2003a: Field evaluation of herbivore-induced plant volatiles as attractants for beneficial insects: Methyl salicylate and the green lacewing, Chrysopa nigricornis. J. Chem. Ecol. 29: 1601-1609. 
JAMES D.G. 2003b: Synthetic herbivore-induced plant volatiles as field attractants for beneficial insects. Environ. Entomol. 32: $977-982$.

JAMES D.G. \& Price S.T. 2004: Field-testing of methyl salicylate for recruitment and retention of beneficial insects in grapes and hops. J. Chem. Ecol. 30: 1613-1628.

James D.G., Price T.S. \& Wright L.C. 2003: Mites and aphids in Washington hops: Candidates for augmentative or conservation biological control. In: Proceeding of 1st International Symposium Biological Control of Arthropods. USDA Forest Service Pub. FHTET-03-05, pp. 189-195.

Johne B., Sprauer S., Weissbecker B. \& Schütz S. 2006: Influence of flower odor compounds on oviposition of the horse chestnut leaf miner Cameraria ohridella (Deschka and Dimic). Mitt. Dt. Ges. Allg. Angew. Entomol. 14: 355-360.

Kalaskar A. \& Evans E.W. 2001: Larval responses of aphidophagous lady beetles (Coleoptera: Coccinellidae) to weevil larvae versus aphid as prey. Ann. Entomol. Soc. Am. 94: $76-81$.

KeSSLER A. \& BALDWIN I.T. 2001: Defensive function of herbivore-induced plant volatile emissions in nature. Science 291: 2141-2144.

Koch R.L., Venette R.C. \& Hutchinson W.D. 2005: Influence of alternate prey on predation of monarch butterfly (Lepidoptera: Nymphalidae) larvae by the multicoloured Asian lady beetle (Coleoptera: Coccinellidae). Environ. Entomol. 34: 410-416.

KuZNETSOv V.N. 1997: Lady Beetles of the Russian Far East. The Sandhill Crane Press, Gainesville, 248 pp.

Lewis W.J., Jones R.L., Nordlund D.A., Gueldner R.C., Teal P.E.A. \& TumLinson J.H. 1982: Kairomones and their use for management of entomophagous insects. XIII. Kairomonal activity for Trichogramma spp. of abdominal tips, excretion, and a synthetic sex pheromone blend of Heliothis zea (Boddie) moths. J. Chem. Ecol. 8: 1323-1331.

Lucas E., Coderre D. \& Vincent C. 1997: Voracity and feeding preferences of two aphidophagous coccinellids on Aphis citricola and Tetranychus urticae. Entomol. Exp. Appl. 85: 151-159.

Lucas E., Labrie G., Vincent C. \& Kovach J. 2007: The multicolored Asian ladybeetle, Harmonia axyridis - beneficial or nuisance organism? In Vincent C., Goettel M. \& Lazarovitz G. (eds): Biological Control: A Global Perspective. Case Histories from around the World. CABI Publishing, Wallingford, pp. $38-52$.

Majerus M.E.N. 1994: Ladybirds. New Naturalist series 81, Harper Collins, London, 368 pp.

Majerus M.E.N., Strawson V. \& Roy H.E. 2006: The potential impacts of the arrival of the Harlequin ladybird, Harmonia axyridis Pallas (Coleoptera: Coccinellidae), in Britain. Ecol. Entomol. 31: 207-215.

MCCLURE M.S. 1986: Role of predators in regulation of endemic populations of Matsucoccus matsumurae Kuwana (Homoptera: Margarodidae) in Japan. Environ. Entomol. 15: 976-983.

Michaud J.P. 2002: Invasion of the Florida citrus ecosystem by Harmonia axyridis (Coleoptera: Coccinellidae) and asymmetric competition with a native species, Cycloneda sanguinea. Environ. Entomol. 31: 827-835.

MichAud J.P. 2004: Natural mortality of Asian citrus psyllid (Homoptera: Psyllidae) in central Florida. Biol. Control 29: 260-269.

Mizell R.F.I.I.I., Frazier J.L. \& Nebeker T.E. 1984: Response of the clerid predator Thanasimus dubius (F.) to bark beetle pheromones and tree volatiles in a wind tunnel. J. Chem. Ecol. 10: 177-187.
Mondor E. \& Roitberg B. 2000: Has the attraction of predatory coccinellids to cornicle droplets constrained aphid alarm signaling behavior? J. Insect Behav. 3: 321-329.

Moraes C.M.D., Lewis W.J., Paré P.W., Alborn H.T. \& TumLINSON J.H. 1998: Herbivore-infested plants selectively attract parasitoids. Nature 393: 570-573.

Moraes C.M.D., Mescher M.C. \& Tumlinson J.H. 2001: Caterpillar-induced nocturnal plant volatiles repel conspecific females. Nature 410: 577-580.

NAKAMUTA K. 1991: Aphid alarm pheromone component, (E)-beta-farnesene, and local search by a predatory lady beetle, Coccinella septempunctata Bruckii mulsant (Coleoptera: Coccinellidae). Appl. Entomol. Zool. 26: 1-7.

Nalepa C.A., Kidd K.A. \& Ahlstrom K.R. 1996: Biology of Harmonia axyridis (Coleoptera: Coccinellidae) in winter aggregations. Ann. Entomol. Soc. Am. 89: 681-685.

Nalepa C.A., Kennedy G.C. \& Brownie C. 2004: Orientation of multicoloured Asian lady beetles to buildings. Am. Entomol. 50: $165-166$.

NaUlt L.R., Edwards L.J. \& STYer W.E. 1973: Aphid alarm pheromones: Secretion and reception. Environ. Entomol. 2: 101-105.

Ninkovic V., Al Abassi S. \& Pettersson J. 2001: The influence of aphid-induced plant volatiles on ladybird beetle searching behavior. Biol. Control 21: 191-195.

Pell J.K. 2008: Ecological approaches to pest management using entomopathogenic fungi; concepts, theory, practice and opportunities. In Ekeski S. \& Maniania N.K. (eds): Use of Entomopathogenic Fungi in Biological Pest Management. Research Signpost, Trivandrum, Kerala, pp. 145-178.

Pettersson J. 1970: Studies on Rhopalosiphum padi (L.) I. Laboratory studies of olfactometric responses to the winter host Prunus padus (L.). Lantbrukshögsk. Ann. 36: 381-399.

Pettersson J., Ninkovic V., Glinwood R., Birkett M.A. \& PiCKeTT J.A. 2005: Foraging in a complex environmentsemiochemicals support searching behaviour of the seven spot ladybird. Eur. J. Entomol. 102: 365-370.

Pickett J.A. \& Griffith D.C. 1980: Composition of aphid alarm pheromones. J. Chem. Ecol. 6: 349-360.

Pickett J.A., Powell W., Wadhams L.J., Woodcock C.M. \& Wright A.F. 1991: Biochemical interactions between plantherbivore-parasitoid. Proceedings of the 4th European Workshop on Insect Parasitoids, Perugia, Italy. pp. 1-14.

Ponsonby D.J. \& Copland M.J.W. 1995: Olfactory responses by the scale insect predator Chilocorus nigritus F. (Coleoptera: Coccinellidae). Biocontr. Sci. Technol. 5: 83-93.

Roy H.E., Brown P. \& Majerus M.E.N. 2006: Harmonia axyridis: a successful biocontrol agent or an invasive threat? In: Eilenberg J. \& Hokkanen H. (eds): An Ecological and Societal Approach to Biological Control. Springer, Dordrecht, pp. 295-309.

Schlyter F., Birgersson G. \& Leufvén A. 1989: Inhibition of the attraction to the aggregation pheromone by verbenone and ipsenol: density regulation mechanisms in bark beetle Ips typographus. J. Chem. Ecol. 15: 2263-2277.

Scutareanu P., Drukker B., Bruin J., Posthums M.A. \& SABELIS M.W. 1997: Volatiles from Psylla-infested pear trees and their possible involvement in attraction of anthocorid predators. J. Chem. Ecol. 23: 2241-2260.

Shimoda T., Ozawa R., Sano K., Yano E. \& Takabayashi J. 2005: The involvement of volatile infochemicals from spider mites and from food-plants in prey location of the generalist predatory mite: Neoseiulus californicus. J. Chem. Ecol. 31: 2019-2032.

Shu S., Grant G.G., Langevin D., Lombardo D.A. \& MacDonALD L. 1997: Oviposition and electroantennogram 
responses of Dioryctria abietivorella (Lepidoptera: Pyralidae) elicited by monoterpenes and enantiomers from eastern white pine. J. Chem. Ecol. 23: 35-50.

SNYDer W.E. \& Clevenger G.M. 2004: Negative dietary effects of Colorado potato beetle eggs for the larvae of native and introduced ladybird beetles. Biol. Contr. 31: 353-361.

Stanton M.L. 1983: Spatial patterns in the plant community and their effects upon insect search. In Ahmad S. (ed.): Herbivorous Insects: Host-seeking Behavior and Mechanisms. Academic Press, New York, pp. 125-157.

Stuart R.J., Michaud J.P., Olsen L.E. \& McCoy C.W. 2002: Lady beetles as potential predators of the root weevil Diaprepes abbreviatus (Coleoptera: Curculionidae) in Florida citrus. Fla Entomol. 85: 409-416.

TAKABAYASHI J. \& Dicke M. 1996: Plant-carnivore mutualism through herbivore-induced carnivore attractants. Trends Plant Sci. 1: 109-113.

ThaLer J.S. 1999: Jasmonate-inducible plant defenses cause increased parasitism of herbivores. Nature 339: 686-688.

THALER J.S. 2002: Effect of jasmonate-induced plant responses on the natural enemies of herbivores. J. Anim. Ecol. 71: 141-150.

Turlings T.C.J., Loughrin J.H., McCall P.J., Ose U.S.R., Lewis W.J. \& TumLinson J.H. 1995: How caterpillar damaged plants protect themselves by attracting parasitic wasps. Proc. Nat. Acad. Sci. USA 92: 4169-4174.

Van WiJK M., De Bruijn J.A.P. \& Sabelis W.M. 2008: Predatory mite attraction to herbivore-induced plant odors is not a consequence of attraction to individual herbivore-induced plant volatiles. J. Chem. Ecol. 34: 791-803.

Verheggen F.J., Fagel Q., Heuskin S., Lognay G., Francis F. \& Haubruge E. 2007: Electrophysiological and behavioral responses of the multicolored asian lady beetle, Harmonia axyridis Pallas, to sesquiterpene semiochemicals. J. Chem. Ecol. 33: 2148-2155.

Verheggen F.J., Arnaud L., Bartram S., Gohy M. \& Haubruge E. 2008: Aphid and plant secondary metabolites induce oviposition in an aphidophagous hoverfly. J. Chem. Ecol. 34: 301-307.

Vet L.E.M., van Lenteren J.C., Heymans M. \& Meelis E. 1983: An airflow olfactometer for measuring olfactory responses of hymenopterous parasitoids and other small insects. Physiol. Entomol. 8: 97-106.

Wei J.R., Yang Z.Q., Hao H.L. \& Du J.W. 2008: (R)-(+)-limonene, kairomone for Dastarcus helophoroides, a natural enemy of longhorned beetles. Agr. Forest Entomol. 10: 323-330.

Zhu J., Cossé A.A., OBRYCKI J.J., Boo K.S. \& BAKer T.C. 1999: Olfactory reactions of the twelve-spotted lady beetle, Coleomegilla maculata and the green lacewing, Chrysoperla carnea to semiochemicals released from their prey and host plant: electroantennogram and behavioural responses. J. Chem. Ecol. 25: 1165-1177.

Received March 17, 2010; revised and accepted May 17, 2010 